\title{
An Analysis of Appraisal System of Paw Patrol Lyric
}

\author{
Dhion Meitreya Vidhiasi \\ mvdhion@gmail.com \\ Akademi Maritim Nusantara Cilacap, Indonesia
}

\begin{abstract}
Hero-themed children's films are always fun for children. The PAW Patrol film series is a spectacle aimed at pre-school-age children. The film's main characters are one 10-year-old child and six puppies. This study aimed to look at the Appraisal System contained in the lyrics of the opening song of the PAW Patrol series, which aired on the NickJr channel. The researcher wanted to find the dominant Appraisal System in the lyrics. The researcher also wanted to know how the lyricist positioned the listeners and viewers of the film through the song's lyrics. The data analyzed were the lyric of the opening song of the PAW Patrol film series. The data were then analyzed using Martin and White's Appraisal System theory. Researchers used qualitative descriptive methods in analyzing the data. The results showed the three Appraisal sub-systems; Attitude, Engagement, and Graduation, are found in the lyrics of the PAW Patrol opening song. The dominant appraisal system was Graduation. Listeners or moviegoers are positioned as people who receive the image of the heroic act shown in the song's lyrics.
\end{abstract}

Keywords: Appraisal system; attitudes; engagement; graduation; PAW Patrol

\section{A. INTRODUCTION}

The world of children is very different from what is experienced by adults. Often, children's imaginations are difficult for adults to understand. A child's imagination can be built in many ways, one of which is through cartoons. Cartoon films that are intended for toddlers are very varied. One of these variations is a film with a heroic theme. Animated film series with the theme of heroism is still easy to follow, namely the Paw Patrol film series. Keith Chapman's PAW Patrol is a Canadian, computer-animated preschool TV program. It is made with animation from the Guru Studio by Spin Master Entertainment. The series, initially seen in the August 2013 previews in Canada, is shown mainly on TVOKids. On August 12, 2013, the series was broadcast on Nickelodeon. The story concentrates on a young kid named Ryder, who heads the PAW Patrol team of search and rescue canines. They operate jointly on missions to safeguard the Adventure 
Bay shoreline and its surroundings. Each dog has specific talents, such as a fireman, police officer, and aircraft pilot based on an emerging service occupation. They all lie in doghouses, which are turned into bespoke cars or 'pup mobiles for their missions.' They are also outfitted with "pup packs," which include instruments relating to the duties of the pups.

The show became a media property, on which an ongoing line of toys was developed. PAW Patrol toy sales generated millions of dollars and increased Spin Master's status in pre-school toy markets. Moreover, the show received many prizes and nominations from organizations like the Canadian Cinema and Television Academy and the Academy of Television Arts and Sciences. Episodes of PAW Patrol have a similar format with repeated themes. Typically, episodes start with a scene depicting the dogs' daily routine, playing with dog toys, and participating in local playground activities. Ryder, a 10-yearold child, knows a problem, whether to seek help or to experience himself. His most often caller is Cap'n Turbot, an accident-prone sea scientist who knows many things about Adventure Bay creatures. With their flashing pet tags, Ryder always alerts the dogs. The members of the group report the lookout and the elevator on their base. Marshall is always the last dog that comes, and the other dogs giggle when the elevator goes up. The situation is funny. They make a straight line when they get to the top floor. Chase deems the team ready to take action, and Ryder tells the pups what happened. He picks numerous team members to resolve each problem, generally two initial responders. By driving a slide down to their automobiles, they complete their mission. When they're done, Ryder says, "Whenever you're in trouble, just yelp for help!" and congratulates the puppies.

The depiction of a person's character in real or in a film can be conveyed through music. Music connoisseurs can often assess the lyrics, rhythm, and word choices used in the song. This also applies to the opening song lyrics of children's films. Children's movie song lyrics always describe how the nature and characters in the film. To encompass evaluation attitudes transmitted by written or spoken discourse Martin (2000) created Appraisal.' It means that he believes our thoughts, views, and attitudes towards one or two of us based on our feeling are evaluated, judged, and appreciated. For example, some people have ideas about things and the world representing ideology, beliefs, and cultures evident in speech choice. Appraisal, said Ulfah (2020), has to do with the negotiation of meanings among real or potential interlocutors. Every utterance enters into processes of 
alignment or misalignment with others, directing us to understand the levels and types of ideology with their readers. According to Pusparini, Djatmika, and Santosa (2017), Appraisal theory relates to language sources where the writer/speaker can express, negotiate, and naturalize the inter-subjective part and ultimately position the ideology. The Appraisal is linked to the SFL language model within the social context, which recognizes the three general social functions we use to which language is used; (i) establishing our social relations; (ii) reflecting each other's experience; and (iii) organizing our actions and representations as meaningful words. (Srinon: 2020)

White (1998) observes that linguistic techniques are central to the notion of evaluation. It expresses, negotiates, and naturalizes various intersubjective perspectives and mainly political ones. Martin (2002) says the same thing in a different way. He emphasizes that the assessment method includes an emotional element, explores our social interactions, and tells our listeners or authors how we feel about questions and persons. Thus, the evaluation framework may presume to reflect our views in a written or spoken sentence. The assessment of the attitude included in the text is defined as an interpersonal system of meaning by Martin \& Rose (2003) as to how an individual communicates how strongly he feels about something and how values are produced in the text. Attitudes can be seen as "blame," meaning that they imply a judgment of the subject, location, situation, and position in a good or negative sense. There are various ways of complimenting, criticizing, or understanding what we do more straightforward or less easy to many individuals. Three types of attitudes exist effect, judgment, and appreciation.

The effect is an assessment of the human subjective reaction. This assessment is the emotional way individuals respond to the problem, the circumstance, and the scenario. The specific circumstance may also be openly or indirectly stated. Abuhasan (2021) said that Affect includes resources for the expression of emotional reactions. This includes, for instance, the use of adverbs (modal adjuncts) such as sadly, adjectives (epithet or attributes) such as sad, as well as verbs (referred to as processes in SFL) such as to upset someone. Affect has been classified by James R Martin \& White (2005) into six factors: (1) Positive or negative; (2) Behavioral process or mental process; (3) Direct or indirect reaction; (4) Feeling graduation; (5) realistic or unrealistic; and (6) Un/happiness, In/security, Dis/satisfaction. The judgment deals with people's behavior. James R Martin 
\& White (2005) classify judgment into two kinds: social esteem and social sanction. The judgment of esteem deals with "normality", "capacity", and "tenacity".

In contrast, the judgment of sanction deals with "veracity" and "propriety". White (1998) initiated an assessment of the shape, appearance, composition, effect, significance, etc., of human things, natural objects, and human persons by referring to esthetic elements and other systems of social value (but not human behavior). It can focus on the qualities of composition. For instance, harmonious, proportionate, fair, and balanced. They are also at a low to a high level, e.g., gorgeous, fabulous, and exquisite. James R Martin \& White (2005) indicate that engagement addresses how the speaker/author stands on the exciting function of resources in quoting/publishing as a forecast, mode, polarity, compromise, and a different statement. Engagement refers to the sort of sentence which constitutes the difference between the author/speaker. Engagement also applies to the term which corresponds to the listener's emotional interests. The mono-gloss and hetero-gloss are two different forms of engagement. The mono-gloss type is the fundamental statement without variations, while changes are required to declare the hetero-gloss type. The hetero-gloss type is broken down into two different types: dialogic contraction and dialogue. Dialogical contractions are alternately employed to dispute, refute or limit this form's scope. Dialogical expansion, by contrast, is a degree of pronunciation that actively permits different roles and voices connected to dialogs. In other words, the room for dialogical contraction ends, whereas dialogical expansion gives way to other perspectives. Both of them are defined by some recorded speech. The distinction is that there is a dialogical contraction and dialogical expansion with verbs for evaluating reporting.

James R Martin \& White (2005) suggest that the contraction of dialogue is split into two subtypes. The object of the disclaimer is rejection, replacement, and firing. The denial and counter-expect are two forms of proclaim. Denial means that the alternative positive stance in the debate, then rejecting. It can also be said that denial is the negative response to a statement, maybe introduced and thus recognized. The counter-planned form includes replacing and deleting a plan in place. The graduation value is linked to the system of importance. The scaling system is employed in two ways. James R Martin \& White (2005) say the force or strength system and the proto-typical system define category boundaries (focus). Zappavigna and Martin (2017) summarized that attitude is concerned 
with types of feeling, graduation with their strength and boundedness, engagement with their sourcing, and acknowledging alternative voices with the feeling being negotiated.

Several researchers have researched the Appraisal System, including Hadidi and Parvin (2015), Agata (2016), Vidhiasi (2021), J. Sutomo (2014), Harti, and Kurniawati (2020), and Hamdani (2021). Agata (2016) examined the prevalence and frequency of application of attitudinal judgment in British publicity texts. Judgment is one of the critical types of attitudes in the semantical discourse assessment model (Martin \& White, 2005 ) with the judgment of the character and conduct of the human being. The essay concentrates on the categories of assessment of capacity and property, as the presented study suggests that these categories of judgment take place the most frequently. In explicit and implicit expression, several typical cases of encoding ability and property are explored. The paper illustrates that the ability of advertising and the inventiveness of the advertising language typically participates in double attitude codings. It is believed that social factors highly drive capacity and propriety: they force ideals upon the potential customer and, thus, on society, creating a social function for the advertising participants. Agata (2016) then said that Appraisal constitutes a unique technique for exploration, description, and explanation of language to assess, take positions, build textual persons, and regulate the positioning and connections between persons. Sutomo (2014) discusses the 2014 APEC Speech by President Jokowi. Sutomo claimed in his studies that President Jokowi was equivalent to other leaders of the state. The numerous behaviors utilized by Jokowi to make his speech are indicative of his assertion. Jokowi can also portray the listener as getting Jokowi to evaluate Indonesia's infrastructure's state and growth plans. The appraisal system of song texts of the GoGo Dino series was analyzed in Vidhiasi (2021).

The outcomes achieved are that the creator of the lyrics utilizes more judgment. The execution of the judgment reveals a person or a superhero, in this case, is valued by the parameters of their behavior. The effects of a person's behavior reaction might result from the behavior parameters. Harti and Kurniawati (2020) researched student's expressions of attitude on covid-19. They say that based on the theory of Appraisal, the study reveals that the composition of the students comprises a range of attitude markers, which represent the most significant proportion of affection; Affect values indicate the student's insecurity and discontent with the subject under discussion. These models should be 
viewed instead of as a precursor because of numerous reasons. Another research on the Appraisal System done by Hamdani (2021) his object of research was an Instagram account named @ officialbistainmadina, particularly concerning the latest 15 comments out of a total of 47 comments made on November 4, 2020. The reference equivalent technique was utilized in this investigation. The results of the study showed that the different types of attitude in these observations tend to utilize one of the three aspects as Attitudes, namely the aspect "like", "delicious", "tempting".

Every animated series always begins with an opening song. This song then made the audience, especially children, more interested in watching the show. Moreover, the song always describes the film, and the Paw Patrol series is no exception. With the implementation of the Appraisal System theory in analyzing a children's movie song lyrics, the researcher can then make predictions about the content delivered in the film. This can make it easier for parents to choose the proper spectacle for their children. Accordingly, this paper aims to find out the Appraisal System contained in the PAW Patrol lyrics and look for the most dominant Appraisal System.

\section{B. RESEARCH METHOD}

The data utilized comes as an introductory song text in the Paw Patrol animated series displayed in NickJr. Therefore, data will be observed and collected through music lyric documentation. The data is then analyzed by Martin and White using the Appraisal theory. Sudaryanto (2015) said that the observation method is a method to collect data by observing the language used in the data.

PAW Patrol, PAW Patrol

We'll be there on the double; Whenever there's a problem; 'Round Adventure Bay

Ryder and his team of pups; Will come and save the day

Marshall, Rubble, Chase, Rocky, Zuma, Skye

Yeah! They're on the way!

PAW Patrol, PAW Patrol; Whenever you're in trouble

PAW Patrol, PAW Patrol; We'll be there on the double

No job's too big; No pup's too small!

PAW Patrol, we're on a roll!

So here we go

PAW Patrol; Whoa-oh-oh-oh

PAW Patrol; Whoa-oh-oh-oh-oh

PAW Patrol!

*Bark*

Figure 1. PAW Patrol Opening Song Lyric 


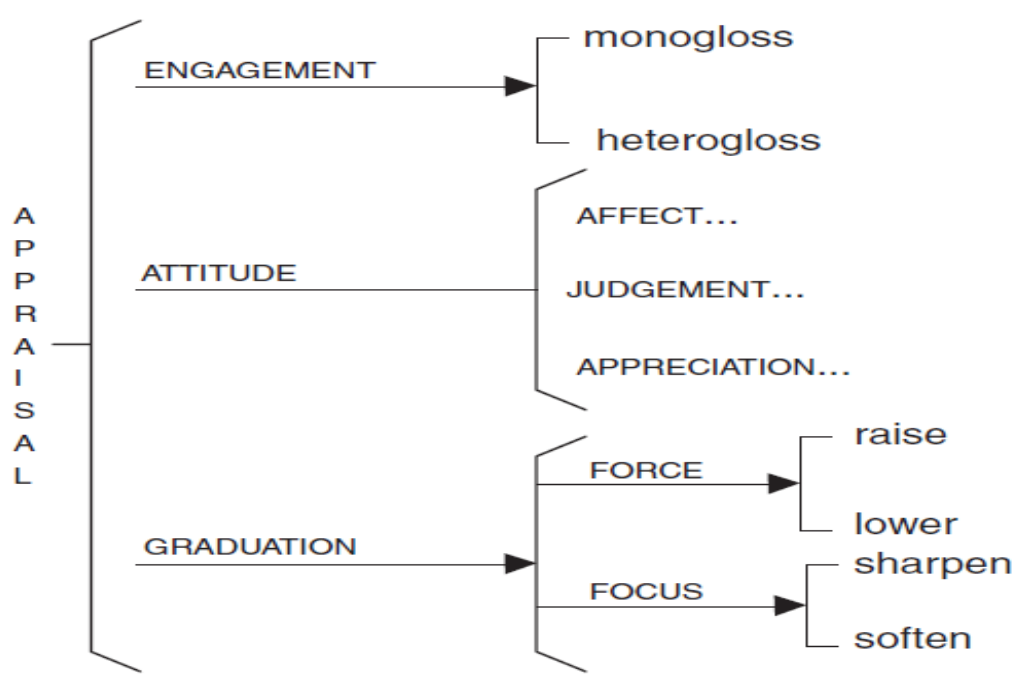

Figure 2. Appraisal Theory (Martin and White: 2005)

The researcher uses descriptive approaches. Polit and Beck (2004) announced that a short investigation would discover the typical event elements and identify and record them. A complete account of the event, situation, or scenario using quantitative, qualitative, or methodological combinations is given in the descriptive analysis.

Existing data is then analyzed with various steps, namely: (1) Data is segmented into words/phrases depending on what is to be explained; (2) Identifying words/phrases based on the Appraisal System theory; (3) Classifying the sentences or words/phrases according to the Appraisal System as proposed by Martin and White (2005). (4). Tabulating the categorized appraisals. (5). Interpreting the findings using the theory proposed by Martin and White (2005).

\section{FINDINGS AND DISCUSSION}

\section{Findings}

The researcher found that the three types of Appraisal systems, namely Attitude, Engagement, and Graduation, were used in the lyrics of PAW Patrol. The frequency of use of each type is shown in table 1 below.

Tabel 1. Appraisal System

\begin{tabular}{clcc} 
No. & Type & Frequency & $\%$ \\
\hline 1 & Attitude & 2 & $25 \%$ \\
\hline 2 & Engagement & 2 & $25 \%$ \\
\hline 3 & Graduation & 4 & $50 \%$ \\
\hline \multicolumn{2}{r}{ TOTAL } & 8 & $100 \%$
\end{tabular}


Of the three types of Attitude that Martin and White, namely Affect, have described, Judgment and Appreciation, only appreciation is found in the lyrics of PAW Patrol. Dialogic contraction, a type of engagement, is found 2 (two) times in the lyrics. As for Graduation, the researcher found a sub-type of Force in the lyrics of PAW Patrol.

Tabel 2. Attitude

\begin{tabular}{cccc} 
Appraisal System & Sub-System & Freq & $\%$ \\
\hline \multirow{3}{*}{ Attitude } & Affect & 0 & 0 \\
\cline { 2 - 4 } & Judgement & 0 & 0 \\
\cline { 2 - 4 } & Appreciation & 2 & $100 \%$ \\
\hline & TOTAL & & $100 \%$
\end{tabular}

It can be seen in Table 2 that appreciation dominates in the three existing subsystems. The two sub-systems can be found in the sentence:

\section{"Whenever there's a problem"}

\section{"Whenever you're in trouble"}

Appreciation is a form of someone's assessment of aesthetics, the process of something happening, or natural phenomena. As for the three Appreciation sub-systems, the two phrases "a problem" and "in trouble" are forms of composition. Something can be said to be "dangerous (problem/trouble)" concerning how one perceives it. That is, the assessment is a person's perception of something.

Likewise, in the lyrics of Paw Patrol, listeners are given the concept that when someone is faced with a dangerous situation, there will be a PAW Patrol who will help. Or in real life concept, there is always help for those in need.

\section{Tabel 3. Engagement - Dialogic Contraction}

\begin{tabular}{cccc}
\multicolumn{2}{c}{ Engagement - Dialogic Contraction } & Frequency & $\%$ \\
\hline \multirow{2}{*}{ Disclaim } & Deny & 2 & $100 \%$ \\
\cline { 2 - 4 } & Counter & 0 & $0 \%$ \\
\hline & TOTAL & 2 & $100 \%$
\end{tabular}

It is known that there are 2 (two) sub-systems of engagement, namely monoglossic and heteroglossic. Disclaim is a sub-system of heteroglossic. However, in the lyrics of PAW Patrol, only 2 (two) heteroglosses are found, namely the use of the deny (denial) type. This usage can be seen in the phrase:

\section{"№ job's too big"}




\section{"No pup's too small"}

The word "no" implies that no work or difficulty is too great and cannot be solved. Although there is a kind of contradiction in real life, there will always be significant difficulties. However, the lyricist wants the audience of the show to have thoughts not to give up.

The author also points out a contradiction between the phrases "no pup's" and "too small" as the size of a puppy is always tiny. No matter how big the dog breed is. However, the lyricist wants to show that physical size is not a problem to help others.

\section{Tabel 4. Graduation}

\begin{tabular}{|c|c|c|c|c|c|}
\hline Appraisal System & & Sub-syste & & $\sum$ & $\%$ \\
\hline \multirow{4}{*}{ Graduation } & \multirow{3}{*}{ Force } & \multirow{2}{*}{ Intensification } & Quality & 2 & $50 \%$ \\
\hline & & & Process & 0 & $0 \%$ \\
\hline & & \multicolumn{2}{|l|}{ Quantification } & 2 & $50 \%$ \\
\hline & \multicolumn{3}{|l|}{ Focus } & 0 & $0 \%$ \\
\hline & & DTAL & & 4 & $100 \%$ \\
\hline
\end{tabular}

The researcher found that there were 4 (four) Graduation systems found in the lyrics of PAW Patrol. However, only the sub-system force is found in the lyrics. The researcher found that the sub-system quality and quantity share an equal amount. The sub-system can be seen in:

"We'll be there on the double" $(2 x)$

"No job's too big"

"No pup's too small"

The phrase "on the double" is categorized in the sub-system quantity. The lyricist wanted to point out that PAW Patrol will immediately help those in need. They will come as soon as possible. The phrases "too big" and "too small" are categorized in the subsystem quality. Coupled with the form of denial at the beginning of the phrase, the lyricist wants to show that size is not helping someone or looking at a problem.

\section{Discussion}

In the Paw Patrol film series, there are seven main characters. They are Ryder, Chase, Marshall, Skye, Rocky, Zuma, and Rubble. PAW Patrol leader Ryder is ten years old. Chase is a German Shepherd that acts as a spy dog and police dog. Smell and vision are 
excellent sensations. He is also allergic to cats and plumage. The police cruiser is his vehicle of the blue tint. Marshall is a timid but skilled Dalmatian, a dog of fire and paramedics. It is also the most commonly utilized pup in most episodes. His fire truck is his car.

Skye is the air pup, and she is a cockapoo. She possesses a helicopter. Rocky is a grey-and-white Schnauzer/Scottish Terrier mix that works as a recycling and handyman dog. He is in charge of the recycling truck. Zuma is a chocolate Labrador retriever that works as a water rescue dog. His vehicle is an orange hovercraft that can travel on both land and water. Rubble is a bulldog that works on construction sites. The bulldozer is his mode of transportation.

The lyrics of the opening song of PAW Patrol can indirectly lift the spirits of the audience. The existence of the Graduation sub-system evidences this. The lyricist gives a level both in terms of the quantity of action and the quality of the size of the problem and the size of the thing. The opening song lyrics then teach children to focus not on the problem at hand but on the actions that must be taken to help someone when they are in trouble. With the implementation of the graduation system, listeners are taught to understand that whatever is done to help someone is vast and meaningful.

The relationship between the lyrics and the film is very synchronous. The PAW Patrol characters are tiny puppies and can help a lot of people. Even though the puppies have the equipment they can always use, the focus remains that helping people is not a size matter. The audience is then positioned as the person who receives and enjoys the lyrics and the PAW Patrol show.

\section{CONCLUSION}

Researchers found there are 3 (three) types of Appraisal systems in the lyrics of the opening song of the animated series PAW Patrol. The three systems are Attitude, Engagement, and Graduation. There is only 1 (one) sub-system of attitude, namely appreciation, found in the lyrics, which explains a form of evaluation of something. Likewise, with engagement, only found sub-system denial in the lyrics. Of the three systems, the most dominant system is Graduation. Lyric writers and filmmakers prefer to show the quality and quantity of a problem or the act of helping someone. Therefore, 
listeners and viewers are positioned as people who receive the heroic act shown in the song's lyrics.

Appraisal System research is fascinating because the researcher can see the meaning behind a word or utterance. This research is still limited to research on the lyrics of children's songs. Subsequent research can be improved with research on state speech or political speech from someone who has tremendous political power or influence.

\section{REFERENCES}

Abuhasan, W. (2021). Argumentative writing: A systemic functional linguistics. https://doi.org/http://dx.doi.org/10.20381/ruor-26163

Harti, S. L. M., \& Kurniawati. (2020). Students' expression of attitude on covid-19related composition: a study on martin and white's appraisal system. Proceedings of the International Joint Conference on Arts and Humanities (IJCAH 2020). 945-948

Hadidi, Y. and Mohammadbagheri-Parvin, L. (2015). Systemic functional linguistics as interpersonal semantics: appraisal and attitude in the stylistic analysis of an English Novel. International Journal of Linguistics, 7(1), 129. https://doi.org/10.5296/ijl.v7i1.7199

Hamdani, Z. (2021). Affect as appraisal system on social media "Instagram." Journal of English Education and Linguistics, 2(1), 60-66.

Martin, J. R. (2000). Beyond exchange: Appraisal systems in English (pp. 142-175).

Martin, J. R. (2002). Meaning beyond the clause: SFL perspectives. Annual Review of Applied Linguistics, 22, 52-74. https://doi.org/10.1017/s026719050200003x

Martin, J. R. and Rose, D. (2003). Working with discourse. New York: Continuum.

Martin, J. R. (2004). Mourning: How we get aligned. London: SAGE

Martin, J. R. and White, P. R. R. (2005). The language of evaluation: The appraisal framework. Lecture Notes in Computer Science, 256.

Polit, D. F. and Beck, C. T. (2004). Nursing research: Principles and methods. 7th edition. Philadelphia: Lippincott Williams \& Williams.

Pusparini, A., Djatmika, \& Santosa, R. (2017). Analisis sistem appraisal berita proses eksekusi duo bali nine (Pendekatan Linguistik Sistemik Fungsional). Paramasastra, $4(2)$

Srinon, U. (2020). Evaluation of Textbook "The language of evaluation: appraisal in english" from the perspectives of thai efl students: implications of systemic functional linguistics and appraisal theory. Studies in English Language Teaching, 8(2), p82. https://doi.org/10.22158/selt.v8n2p82

Sudaryanto. (2015). Metode dan aneka teknik analisis bahasa. Yogyakarta: Sanata Dharma Univ. Press.

Sutomo. J. (2014). Appraisal system recognized in president jokowi's speech at the APEC SEO Summit 2014 in Beijing, China J. Sutomo FBIB, Universitas Stikubank Semarang. 19-35.

Ulfah, A. P. (2020). Appraisal system in syllabus of same-sex marriage legal document of the United States: A Systemic Functional Linguistics Approach (Thesis). 
Vidhiasi, D. M. and Soepriatmadji, L. (2011). Appraisal system recognized in the Jakarta Post's editorial "The Asean Cage" on July 20th, 2011. In dinamika bahasa dan budaya, vol. 7, no. 1, pp. 28-41. Semarang: Universitas Stikubank.

Vidhiasi, D. M. (2021). Appraisal system in GoGo Dino theme song Indonesian translation lyric. 2015, 110-123. https://doi.org/10.20884/1.jli.2021.12.1.

White, P. R. R. (1998). Telling media tales : the news story as rhetoric.

Zappavigna, M. and Martin, J.R. (2018). Discourse and diversionary justice: An analysis of youth 